Georgia State University

ScholarWorks @ Georgia State University

\title{
FDR, the Rhetoric of Vision, and the Creation of a National Synoptic State
}

\author{
Mary Stuckey \\ Georgia State University, mstuckey@gsu.edu
}

Follow this and additional works at: https://scholarworks.gsu.edu/communication_facpub

Part of the Communication Commons

\section{Recommended Citation}

Stuckey, M. (2012). FDR, the Rhetoric of Vision, and the Creation of the National Synoptic State. Quarterly Journal of Speech, 98(3), 297-319. DOI: 10.1080/00335630.2012.691172

This Article is brought to you for free and open access by the Department of Communication at ScholarWorks @ Georgia State University. It has been accepted for inclusion in Communication Faculty Publications by an authorized administrator of ScholarWorks @ Georgia State University. For more information, please contact scholarworks@gsu.edu. 


\title{
FDR, the Rhetoric of Vision, and the Creation of a National Synoptic State
}

\author{
Abstract \\ Throughout his administration, FDR engaged in a complex set of arguments that worked together \\ to defend democracy in general as a viable form of government; American democracy as the \\ highest expression of democratic government; the primacy of the federal government as the most \\ efficient and effective locus of democratic power; and the executive office as the culmination of \\ the form, efficiency, and locus of that power. My specific concern here is with one form those \\ arguments took, the visual metaphors that permeate FDR's rhetoric. Visuality in FDR's rhetoric \\ is especially intriguing because of the way it interacted with the prevailing political culture in \\ order to underwrite radical shifts in political power by helping FDR persuade the mass public to \\ accept a synoptic view of nationalism and governmental responsibility. These changes have \\ implications for presidents, presidential candidates, and for the citizens whose support they seek.
}




\section{FDR, the Rhetoric of Vision, and the Creation of a National Synoptic State}

We take the size and power of the federal government for granted. Even those who object most to "federal intervention" in national affairs have trouble locating precise areas in which they do not want governmental involvement, and have, since Ronald Reagan first issued his call to "get government off the backs of the American people," consistently supported legislation increasing federal power in various aspects of our national life. ${ }^{1}$ We take the president's role in the federal government for granted as well. It is “the president's budget,” and "the president's agenda,” and while there are debates about the efficacy of presidential efforts to lead public opinion no one seriously questions the ubiquity of such efforts. ${ }^{2}$ While political scientists and historians situate these changes in the 1930s and 1940s and credit Franklin D. Roosevelt with the impetus behind them, ${ }^{3}$ very little research has been done on the persuasive work that fostered Roosevelt's articulation of primacy for U.S. federal government in general and for the person of the president very much in particular. ${ }^{4}$ Those articulations, significant in Roosevelt's day, remain important exigencies for presidents and presidential candidates.

At the time of FDR's ascension to office and throughout his administration, there were loud and contentious debates about the appropriate forms a modern democratic government could and should take. ${ }^{5}$ These debates concerned the best way to ensure efficiency in the midst of crisis on the one hand and preserve democracy in the midst of a world that seemed increasingly prone to militarism, communism, and fascism on the other. ${ }^{6}$ In this political context, FDR engaged in a complex set of arguments that worked together to defend democracy in general as a viable form of government; American democracy as the highest expression of democratic government characterized by a specific kind of citizenship; the primacy of the federal 
government as the most efficient and effective locus of democratic power; and the executive office as the culmination of the form, efficiency, and locus of that power. These arguments underwrote changes that continue to affect the practices of the chief executive and the rhetoric of those who aspire to that office. ${ }^{7}$

These arguments were defended in a wide variety of ways throughout the Roosevelt administration. Presidential rhetorical competence has always been an important aspect of success in the office, ${ }^{8}$ but the nature of that expertise changes over time and across media. ${ }^{9}$ FDR was famous in his own day as well as in ours as a master of the press ${ }^{10}$ and is widely understood as the first president to take serious advantage of radio, ${ }^{11}$ both of which are often cited as the reason for his extraordinary relationship with the mass public. ${ }^{12}$ There is also evidence that he made astute use of newsreels. ${ }^{13}$ As the nation moved from a reliance on print media to more visual communication on the one hand and an entirely aural form of communication on the other, FDR operated at the intersection of these communicative forms. ${ }^{14}$ Roosevelt's communicative talent is widely acknowledged. ${ }^{15} \mathrm{He}$ is regarded as a progenitor of press management ${ }^{16}$ and as a rhetor of uncommon skill. ${ }^{17}$ His persuasive discourse is often understood as one of the foundations of his presidency ${ }^{18}$ if not as the major reason for its success. ${ }^{19}$ Roosevelt's communicative skill is unquestioned and unquestionably integral to his political success.

My specific concern here is with one way in which that skill was displayed, the visual metaphors that permeate FDR's rhetoric, and which, to use Michael Osborn's terms, set his argument before his listeners' eyes, and invited them to see as he saw, to accept his role as their representative. ${ }^{20}$ Davis W. Houck has convincingly demonstrated the importance of Roosevelt's visual rhetoric as a mechanism that assisted his efforts to camouflage his disability and attain the presidency. ${ }^{21}$ Houck's analysis of FDR's use of bodily and sensate metaphors reveals an 
important function of that rhetoric. Presidential embodiment is, as Houck shows, a rich site of rhetorical analysis, and his work reveals important insights into the associations between the president's body, perceptions of the nation's political health, and the gendered nature of the institution of the presidency.

But as Cara Finnegan notes, Roosevelt’s visual rhetoric operated on many levels, ${ }^{22}$ including educating the public, providing reassurance, and encouraging mobilization. ${ }^{23}$ Certainly, as Finnegan also observes, this language “echoes a larger cultural shift in Depressionera modes of knowledge and representation,”24 reflecting the era’s conflation of "seeing” and “knowing.” Her work concentrates on the cultural shifts revealed and enabled by this conflation, which pointed to "visual remedies” for the nation's ills. ${ }^{25}$ For Finnegan, a documentary form of seeing led credence to specific forms of representation and supported certain kinds of policies. Building on those insights, I am interested here in the institutional remedies whose warrants were frequently framed in visual language, namely, the shift in political power from the state and local governments to the national government, and within the federal system from congressional to presidential centrality.

The persuasive work associated with these shifts was extensive and encompassed nonvisual as well as visual language. But ocular metaphors were particularly useful for they resonated with the era's cultural emphasis on authenticity and helped render much that was unfamiliar more proximate. ${ }^{26}$ Visuality in FDR's rhetoric is especially intriguing because of the way it interacted with the prevailing political culture in order to underwrite radical shifts in political power by helping FDR persuade the mass public to accept a synoptic view of nationalism and governmental responsibility. ${ }^{27}$ These changes organized government and citizenship in particular ways. In order to facilitate national planning and a national program, 
Roosevelt had to develop a national vision. In James C. Scott's terms, he had to see like a state. ${ }^{28}$ But he also had to encourage the nation to participate in this new way of understanding politics. ${ }^{29}$ In so doing, he fundamentally changed the nature of the federal government and its relationship to the national citizenry.

My argument proceeds in three parts. First, I briefly discuss the national crisis that provided both the context and much of the impetus for Roosevelt's political actions. I then turn to the political shifts that occurred during the Roosevelt years and to the visual language that helped accomplish the persuasive work authorizing those shifts. I conclude with a discussion of the consequences of the Rooseveltian revolution and the synoptic state it engendered.

\section{Democracy in Crisis}

As the world depression deepened in the early 1930s, it was no wonder that governments teetered and collapsed. ${ }^{30}$ By 1933, national unemployment in the United States ranged somewhere between 25 and 37 percent, depending on how the data were calculated. ${ }^{31}$ In some places, it hovered at around 80 percent. $^{32}$ Business investment was 90 percent lower than it had been a mere four years previously. ${ }^{33}$ In the same period, the American Gross National Product fell by 30 percent while farm prices fell by twice that number and industrial production was halved. ${ }^{34}$ On a more human level, the suicide rate rose dramatically ${ }^{35}$ while homes were being lost at the rate of a thousand a day, throwing families into the streets and overwhelming what little sources of relief states and localities were able to provide. ${ }^{36}$ According to Secretary of the Interior Harold Ickes, upon whom much of the administration of relief would fall, "Millions of people were half fed . . .barely clothed . . . and living more like kennelless dogs than human beings.” ${ }^{37}$ The poverty and dislocations caused by the economic cataclysm—physical, social, economic, and psychological—cannot be imagined by those of us who did not experience them 
directly. Those who were there searched for comparisons through which they could make the disaster intelligible. When asked if he'd knew of anything comparable to the Depression, for instance, economist John Maynard Keynes replied affirmatively, adding, “it was called the Dark Ages, and it lasted four hundred years.” ${ }^{38}$ Prevailing theories of government and economics were all but entirely discredited and the way forward was unclear at best. ${ }^{39}$

In this context, it was doubtful that the traditional forms of government could or should be saved. ${ }^{40}$ As “radio priest” Father Charles E. Coughlin put it in 1934, "Truly, democracy itself is on trial." ${ }^{41}$ Challenges to traditional structures pervaded popular culture, up to and including arguments for dictatorship. ${ }^{42}$ Such calls were associated not only with Roosevelt as a personality but also with an increasing fear that without dictatorial powers in the hands of a strong executive, order would be impossible. These fears were exacerbated by continuing threats to that order. In 1934 alone, for instance, 1.4 million workers went on strike, ${ }^{43}$ and there were widespread indications that people were rapidly losing their respect for and fear of the law. ${ }^{44}$ Interestingly, the response to the economic disaster was not always expressed as violence or panic, but often as depression, alienation, resignation, despair, and as individual failure and self-blame. ${ }^{45}$ The entire nation felt these consequences directly or indirectly as all the old verities and the hierarchies associated with them crumbled.

Events abroad were equally disconcerting. Hitler's rise paralleled Roosevelt’s own, and Japan’s increased militarism created very real concern about the repercussions for American interests in Asia. ${ }^{46}$ The United States, isolated and prosperous throughout the 1920 s, retained its isolationism if not its prosperity throughout the 1930s, but as the decade progressed citizens became increasingly agitated by the fear that events abroad would impel the nation into another cataclysmic war. ${ }^{47}$ 
Roosevelt's election in 1932 may have provided hope, at least on the domestic front, but it solved nothing. FDR campaigned on a promise to initiate "bold, persistent experimentation,”48 in addressing the national economic crisis. But the Depression, punctuated by mild bouts of recovery, continued into the early 1940s. International tensions ebbed and flowed throughout the period, culminating in the attack on Pearl Harbor and the bloodbath of world war. ${ }^{49}$ While Roosevelt responded to these events by attempting to modernize and reorganize what passed for the American state, he met considerable resistance. His goal was to centralize political administration, to make it more efficient, more amenable to wide scale planning; in a word, to render American politics more synoptic. Throughout his entire time in office FDR argued that democracy was viable, especially in the United States, which nurtured a certain kind of citizen, and that the best hope of preserving democracy was a strong national government headed by a strong president. These arguments were often made in language that evoked the visual.

\section{Roosevelt's Synoptic State}

To address the unprecedented national crisis, Americans were willing to endorse sweeping changes, especially in the initial days of FDR's first term, including grants of extraordinary power to the national government and to its chief executive. Importantly, the scope of these changes, if not their consequences, was clearly understood at the time. ${ }^{50}$ FDR's plans thus had to be defended publicly and often, for serious danger lay in the issue of how the acquisition of power would be read in a global context that included the American fear of the Soviet Union and the rise to power of dictators in Germany and Italy. ${ }^{51}$ In the face of challenges to the viability of democracy posed by the economic crisis and these dictators, Roosevelt argued that he was committed to both preserving and modernizing the forms of democratic governance in the United States. ${ }^{52}$ Visual language was integral to this effort. 
In many ways, national government requires that the nation be rendered visible. ${ }^{53}$ Importantly, the imperatives behind this requirement are market-driven; increased national rationalism is connected to increased national productivity and access to markets. ${ }^{54}$ Rationalism is attained through making the nation visible and thus amenable to hierarchical ordering. In this process, its multitude of disparate elements must be abstracted, ordered, rendered legible. This legibility implies a central position from which the nation can be seen, understood, and managed, so national government and administration are required. This was a difficult challenge for Americans to meet in the 1930s, for as many scholars have noted, there is a problematic relationship between visuality and democracy. ${ }^{55}$ Citizens want to be able to see their leaders and they want those leaders' actions to be transparent in ways that directly contrast to a monarchy's reliance on ritual. ${ }^{56}$ Democratic display needs to be more symbolically oriented toward accountability than toward spectacle, ${ }^{57}$ a need that reflects belief in a specific kind of audience, one that is attentive, witnessing, and capable of rational deliberation, even while organization on a mass scale works to reduce the importance of any singular individual. ${ }^{58}$ The state must be seen even as it makes the nation visible and the processes of accomplishing this must be understood as transparent if they are also to be understood as democratic. ${ }^{59}$ In making this transition to a synoptic state, Roosevelt's first step was to argue that democracy was not only a viable but also an intrinsically superior form of government.

"I Paint it For You in Hope" ${ }^{60}$ : The Viability of Democracy

Despite the widespread belief that the Depression provided inescapable evidence that democracy could not survive, ${ }^{61}$ Roosevelt argued that it remained viable and was, indeed, the system of government most likely to return the world to economic stability, revealing the close relationship presidents have always fostered between economic capitalism and political 
democracy. For Roosevelt, democracy was not only the truest expression of the best of human nature but also the system most likely to ensure that its citizens were productive and prosperous as well as happy. ${ }^{62}$ In 1934, for example, he vividly depicted the days before his election:

Individuals were seeking quick riches at the expense of other individuals. Geographical sections were seeking economic preference for themselves to the disadvantage of other sections. Cities were recklessly offering inducements to manufacturing plants to move away from other cities. Within given industries unfair competition went on unheeded or resulted in vast consolidations whose securities were peddled to the public at dishonest prices. There was little consideration for the social point of view, and no planning whatsoever to avoid the pitfalls of overproduction or of selling methods which foisted articles on a gullible public, which the family budget could not afford. ${ }^{63}$

Blame for the economic crisis was specifically located in a poor use of vision. Roosevelt argued here that he understood the causes of the national calamity (unwise searching) and where to affix the blame for it. This is consistent with his tendency, as Thomas Farrell notes, to put malevolence in the past, as already remedied. Consequently, while blame was clearly fixed, punishment was also not required. ${ }^{64}$ In this depiction, the "gullible" mass of citizens were described as victims of ignorant and unscrupulous business practices and of a government that had not cared enough to intervene. Under his administration, Roosevelt argued, ignorance was being corrected, business practices were being reformed, and government was instituting a better way of seeing, a "social point of view." This perspective required planning to achieve the results it promised. Democratic capitalism as a system was, in this depiction, sound; its ill were correctable and were being corrected. All that was required for this correction was an endorsement of Roosevelt’s government which embodied “the social point of view.” 
Democracy, according to FDR was the form of government most able to instantiate this perspective. Roosevelt thus urged reform rather than revolution. In his first inaugural, more noted for his willingness to assume extraordinary power than for his reliance on American traditions of limited government, he said, “Action in this image and to this end is feasible under the form of government which we have inherited from our ancestors. Our Constitution is so simple and so practical that it is possible always to meet extraordinary needs by changes in emphasis and arrangement without loss of essential form.” ${ }^{65}$ Roosevelt thus argued that nothing drastic needed to happen to existing structures in order to produce drastic results. This is the rhetoric of purification, ${ }^{66}$ not revolution: "It is our task to perfect, to improve, to alter when necessary, but in all cases to go forward.” ${ }^{67}$ FDR prized movement and activity; for him stagnation was political death. ${ }^{68}$ But, he argued, he did not intend to make changes to the fundamentals. He was only interested in changing them enough to bring them in line with the modern world. ${ }^{69}$

FDR seems to have assumed that any necessary economic reforms would be produced indirectly through a modernized political system that focused on the provision of social justice, represented as light rather than opposing darkness: "These dark days will be worth all they cost us," he said in his first inaugural, "if they teach us that our true destiny is not to be ministered unto but to minister to ourselves and to our fellow men.”70 The task of government under FDR was to facilitate the New Deal ministry. ${ }^{71}$

That ministry was based on a Christianized view of government responsibilities, which included a major emphasis on the idea of social justice through improved government. For Roosevelt, democracy, religion, ${ }^{72}$ and civilization were all intimately connected. He could not envision any one of these without the others. Under his administration, citizens saw the nation in 
the same terms. One correspondent told the president that, "I believe the old age pensions, aid for crippled children and unemployment insurance are essential to a human and civilized society, to say nothing of a supposedly Christian nation."73 Others complained that New Deal programs (especially repeal of Prohibition) were "running rough shod over the teaching of Christianity."74 In both these cases, and in others like them, the expectation was that the nation would be governed in ways that were congruent with “Christian” theology.

Roosevelt encouraged the nation to understand world history as an upward trajectory in which human rights and individual freedom were increasingly realized. "With every passing year,” he said, “I become more confident that humanity is moving forward to the practical application of the teachings of Christianity as they affect the individual lives of men and women everywhere.”75 Relying here as in so much of his public speech, on values and images associated with mainstream Christianity, he explicitly applied Christian teleology to political life. ${ }^{76}$ An example from 1938 encapsulates much of this tendency: "Clearer every day is the one great lesson of history — the lesson taught by the Master of Galilee-that the only road to peace and the only road to a happier and better civilization is the road to unity-the road called the 'Highway of Fellowship.' But as the community of interest becomes apparent to those who live on farm and in city, the strategy of the cold-blooded few to divide and conquer, to make common men blind to their common interests, becomes more active." ${ }^{77}$ This glorious compendium of mixed metaphors rests on a visual foundation. Not only did the vision increasingly available to the mass of Americans through FDR pose a threat to those he characterized as "the cold-blooded few," but that in turn opened up a new clarity of vision for them, who were able to perceive the exact nature of the threat and move to counter it. The more clearly "the cold-blooded few" saw, the more determined they became to darken the vision of the rest of the nation. Those who could 
not see clearly were so deluded that they would attempt to delude others. Roosevelt, like the “Master of Galilee,” could see the correct road, the road that led to a "happier and better civilization.” Because of this clarity of vision, he was able to unmask the machinations of his Republican opposition. FDR thus identified vision as the site of struggle; the contest was not over citizens' “hearts and minds” in today's tired parlance, but over their eyes, for the proper mode of seeing was the condition for victory in the political struggle.

Calling on the rhetorical traditions of western civilization, clear sightedness was equated with clear thinking in the Rooseveltian vocabulary. Thus, both foreign and domestic threats were portrayed as "shadows"78 or in metaphors that conjured darkness or in one way or another obscured vision. He spoke of “clouds of suspicion,”"79 and of “menacing clouds,” 80 of a potential "black out of peace," ${ }^{81}$ of "nations without light," 82 and of his determination that "we will never permit, if we can help it, the light to grow dim.” ${ }^{83}$ Preserving the light required consciously avoiding deception. In 1940, for instance, in a message asking for increased defense appropriations, he said, "Let us examine, without self-deception, the dangers which confront us. Let us measure our strength and our defense without self-delusion.” ${ }^{84}$ For Roosevelt, illusions, deceptions, and lies were all elements that created darkness; collectively, American citizens would arrive at an accurate picture in the light of reality. "It is not in despair that I paint you this picture,” he said in his second inaugural. "I paint it for you in hope-because the Nation, seeing and understanding the injustice in it, proposes to paint it out." 85 Roosevelt equated vision, understanding, compassion, and national unity, all of which were critical elements in his invitation to participate in a national synoptic state. There is abundant evidence that citizens accepted this invitation: In late 1935, for instance, Roosevelt sent letters to the national clergy asking for reports on local conditions and opinions. Some 7,000 clergymen replied. Both his 
critics and his supporters included information about the smallest of local details and related those details directly to the need for the president to understand local conditions in order to make wise and compassionate national policy. ${ }^{86}$

It is clear, then, that Roosevelt argued with some effect in response to both internal and external challenges that democracy was not only viable but was the system most in keeping with human development. Democracy stood opposed to oppressive regimes such as Communism and Fascism, and, once its structures were modernized, it would return to its former goals and provide economic prosperity and social justice. He justified this faith in democracy as a system through the example of its enactment in the United States, which for Roosevelt, served as the exemplar of world democracy. In this vision, citizens held a central place.

\section{"Widen the Orbit of Vision" ${ }^{87}$ : Citizenship in the Synoptic State}

Because of this faith in the teleology of democracy, Roosevelt argued that the American people collectively had vision, and as president, he served that vision: “As the humble instruments of their vision and their power, those of us who were chosen to serve them in 1932 turned to the great task, ${ }^{88}$ he told a Wisconsin audience in 1934. Because of the clarity and perspective his office provided, he could see what the mass of Americans saw-but he could see it more clearly than they. Their vision was individual; his task was to perceive, collate, and enact that vision into a singular national vision. He was the agent of the people, the instrument of their will, but as that agent, he had a unique perspective because he could see the whole while others were limited in their vision to a part of that whole. He thus mobilized visual language as a way of defining synoptic citizenship.

The people's vision was informed by the national government and also informed that government’s larger vision. Ocular citizenship was also therefore inherently democratic. FDR 
argued in 1940 that "the crash of swiftly moving events over the earth has made us all think with a longer view." ${ }^{89}$ He encouraged his audience to "look ahead and see” the consequences of the burgeoning war, and said, "Summing up this need of looking ahead, and in words of common sense and good American citizenship, I hope that we shall have fewer American ostriches in our midst. It is not good for the ultimate health of ostriches to bury their heads in the sand." ${ }^{90} \mathrm{He}$ opposed those at home and abroad who were willfully narrow in their outlook-the capitalists who opposed the New Deal, the isolationists who opposed American intervention in the European war, and the Fascists who opposed democracy were united in their inability to see beyond the selfish needs of the moment. Democratic citizens in a synoptic state, on the other hand, were characterized by their ability to see clearly, to take the "longer view."

By virtue of their position, presidents had a specific sort of responsibility vis-à-vis individual citizens: "For a President especially it is a duty to think in national terms. He must think not only of this year but of future years when someone else will be President. He must look beyond the average of the prosperity and well-being of the country, for averages can cover up danger spots or poverty and instability."91 The president's job was to look beyond, to see farther and more deeply than anyone else, to survey the entire nation and to act on the shared national vision. Poorly perceived nationalism was dangerous, for averages were potentially deceptive. Only a clear-sighted nationalism, firmly grounded in democratic norms, would be able to perceive and act upon true national needs. It was a bottom up vision that found expression from the top down, as supporters found themselves seeing "eye to eye” with the president. ${ }^{92}$

Not everyone agreed with the president's vision. One of the president's critics noted, for example, that those "who try to think clearly and are far-seeing" are and "always will be in the minority." 93 Another critic accused him of “shadow boxing with realities." ${ }^{94}$ Regardless of 
partisan affiliation, the political argument was often couched in visual terms. A number of citizens writing to Roosevelt, for example, often commented on the clarity of his vision. ${ }^{95}$ They also wanted him to see as they saw. They sent him postcards, church bulletins, pictures of all kinds so that he could see and thus understand local conditions and consequently make better national policy. ${ }^{96}$ His critics also responded with sometimes scathing comments on local conditions. ${ }^{97}$ In all these cases, citizens were working to create a shared national vision by trying to influence the president's perception of the nation. ${ }^{98}$ Citizenship required sharing vernacular visions with national actors, for only a national government could see and thus govern the entire nation.

\section{"The Whole Picture" ${ }^{99}$ : Federal Primacy}

Roosevelt took office with a mandate for "undelayed action," 100 and for him that meant federal action. While FDR receives most of the credit for the barrage of legislation that was the Hundred Days, it is also true that during those days he encouraged congressional initiatives, a fact that may well explain his very productive and generally cooperative relationship with his first Congress. ${ }^{101}$ Members of the public soon learned to look to the federal government for help, and this fact alone wrought enormous changes in the relationship between the people and their government. ${ }^{102}$ It was not uncommon for citizens to tell FDR that, “Only the Federal Government can put a stop to such abuses.” ${ }^{103}$ Halford R. Ryan argued that "First, the political and philosophical theses of FDR's New Deal rhetoric were that the presidency and Congress had the legal power and the political obligation to address a national Depression at the national level with national legislation.” ${ }^{104}$ This is critical to understanding Roosevelt's defense of federal primacy because a central tenet of that defense was the claim that, "We have undertaken a new order of things: yet we progress to it under the framework and in the spirit and intent of the 
American Constitution." ${ }^{105}$ Roosevelt was continually defending the legalities of his moves under the Constitution, defenses that would not have been needed if the moves had been less controversial.

One way he managed these controversies was by manipulating images in a form of antithesis. Roosevelt often placed images in proximity to one another, inviting audiences to "see" the differences between them. He was especially fond of images relating to size, enabling him to reduce complicated ideas and sprawling policies to manageable dimensions. He was also able to reduce the significance of his opponents by rendering them into "small minorities" with "petty concerns” who needed to be stopped from wielding large and thus disproportionate power. ${ }^{106}$ These people were consistently placed in opposition not just to FDR, but also to the "vast majority” of Americans who agreed with him on whatever policy was under discussion. ${ }^{107} \mathrm{By}$ manipulating size, FDR also evoked the audience's visual acuity: big things became small and small things became big. It was common for him to assert that, "There are, of course, men, a few men, who might thwart this great common purpose by seeking selfish advantage." ${ }^{108}$ His majorities were rarely just majorities—-they tended to be "overwhelming," 109 just as the groups who opposed him were generally "small." ${ }^{110}$ This manipulation of size—big majorities who were relatively powerless facing small minorities who had disproportionately large power—had both political effects, in that it encouraged national unity, and potentially disorienting effects, in that it called for a change in one's understanding of reality through a sensual experience of altered size and proportion. ${ }^{111}$

This is better understood as antithesis than as amplification and reduction because the rhetorical power doesn't come primarily from the manipulation of size alone but from the immediate juxtaposition of different sizes of things. That is, Roosevelt did not just sometimes 
refer to his opponents as small and at other times as his supporters as large; these two characterizations almost always appeared together. In addition, small groups were often depicted as having large amounts of power, and also as making small problems or issues appear larger than they in fact were. ${ }^{112}$ In his fourth Fireside Chat, for instance, he said, Because in every step which your Government is taking we are thinking in terms of the average of you —in the old words "the greatest good for the greatest number"—we, as reasonable people, cannot expect to bring definite benefits to every person or to every occupation or business, or industry or agriculture. In the same way no reasonable person can expect that in this short space of time, during which new machinery had to be not only put to work, but first set up, that every locality in every one of the forty-eight States of the country, could share equally and simultaneously in the trend to better times. The whole picture, however — the average of the whole territory from coast to coast - the average of the whole population of $120,000,000$ people-shows to any person willing to look, facts and action of which you and I can be proud. ${ }^{113}$

Notice how he manipulated size via companion terms throughout this passage. The federal government was positioned as able to see and thus to understand the entire nation, from its largest incarnations to its smallest details. He began with “every step," and a concern for "the average," followed by “the greatest number," who needed “definite benefits” for "every person or to every occupation or business," a single "reasonable person," “every locality in every one of the forty-eight states," “The whole picture," “the average of the whole territory” and "the average of the whole population,” and concluded with "any person.” The swelling and reduction of the nouns in this one brief passage is downright vertiginous. This dislocation allows for relocation — distance was reduced and propinquity established. The distances between his 
auditors and between his auditors and himself were bridged and the audience invited to see as FDR saw, to participate through him in an embodied politics in which he represented the shared perspective of the audience. ${ }^{114}$

Importantly, this passage both depicts the entire nation and rests on a visual metaphor. The national government was positioned as having unique access to the "whole picture,” and as able to elucidate it to "any person willing to look." The task of the national government was to apprehend the national "picture," and the task of the citizen was to be "willing to look" at that picture as it was explained to them by the president-who assumed interpretive authority over the nation.

\section{“He Must Look Beyond"}

Unlike the shift from a local to a national policy orientation, the establishment of presidential political dominance implied personal as well as institutional power. This connection caused Roosevelt enormous difficulties, for it was here that the allegations of dictatorship resonated most deeply. ${ }^{116}$ There was simply no denying that his leadership was indeed strongly centered in the person and personality of the president. In part, this was probably an artifact of his medium of communication. ${ }^{117}$ But in part, it was also an artifact of Roosevelt's rhetoric and the ways it resonated with the public. For example, one minister replied to the president's request for information about local conditions and needs by asking for farm equipment. “A single tractor,” he noted, “properly placed, could do much to take care of many garden plots and the expense would be trifling."118 This clergyman felt able to ask the president to satisfy a purely local need. In another example, a bishop told the president that, "You have tried to build a bridge between the dim visions of unhappy, restless men and women, and the victorious realization of 
those visions." ${ }^{119}$ For these correspondents, vision and the reduction of distance were related, if in ways that seem grammatically obscure.

This linkage was crucial, because both the reduction of distance and the personal trust engendered by this rhetorical intimacy were powerful elements authorizing the shift in institutional power. William H. Watts, for example, wrote to the president, "I have thought all along that you, Mr. President, and the men of undoubted integrity to whom you have entrusted the carrying out of your plans know best what ought to be done and the best way to do it.” 120 Citizens like Watts “recognized” FDR’s superior vantage point and authorized action in keeping with that superiority.

Roosevelt consistently claimed that while democracy was viable and that in the United States it found its clearest and most vibrant expression, the previous decade had corrupted the system, thus requiring restorative action. That action could only be effective if it was carried out by a national synoptic state. "In the White House today,” he said in 1940, “we have built up a great mosaic of the state of the union from thousands of bits of information-from one man or woman this thought; from another, data on some event; a scrap here perhaps and a scrap there; from every Congressional district in the Union and from rich and poor; from enthusiast and complainant; from liberal and conservative; from Republican and Democrat." ${ }^{121}$ Here Roosevelt portrayed himself as an artist crafting a mosaic from tiny bits of unrelated materials. Only he could see the whole before the mosaic was completed; his internal vision determined the final shape. He was both the instrument of the people and the guiding hand of national unity. As an agent his was the task of ordering and disciplining the visual in the service of national goals. But as the agent, he had a perspective on those goals no one else could match. 
The president was not only graced with a certain perspective but also obligated to act upon it. He said, “Nevertheless, as the Executive head of Government, I am compelled to look facts in the face.” ${ }^{122}$ The ethotic element of this visual language allowed him to argue for his definitions as the correct definitions; they were not a matter of contention, but were "recognized" truths. His perspective ultimately trumped that of anyone else. ${ }^{123}$ In arguing for the dominance of his perspective he was also implicitly arguing for the dominance of the executive over the legislative branch at the national level and for the national government over those of localities as well. If perspective was the determining force of solid public policy, power should follow it. But perspective wasn’t the only visual element supporting Roosevelt's claim to authority. He could not only see farther than others, he could also see more clearly.

If a national perspective gave the president the obligation to assume power over the more limited perspectives of local governments and the national legislature, his clarity of vision gave him the obligation to outline the details of policy aimed at the national situation. Roosevelt consistently declared that things were “evident,” or “clear.” He constantly dispelled "illusions” and often claimed that we could not afford to be "blinded" by erroneous claims, dreams, or other misapprehensions $^{124}$ and facilitated a shared national vision. ${ }^{125}$

That shared national vision was remarkably intimate. Through his use of depiction, FDR combined form and content to legitimate his claim to see for and thus to act for his national constituency. ${ }^{126}$ The intimacy he thus established is one of the hallmarks of his communication ${ }^{127}$ and correspondents sometimes addressed him as "Frank," or referred to him in familial or other kinds of familiar ways. ${ }^{128}$ One of the best examples of such depiction is his 1944 Christmas Eve Address to the nation: 
The Christmas spirit lives tonight in the bitter cold of the front lines in Europe and in the heat of the jungles and swamps of Burma and the Pacific islands. Even the roar of our bombers and fighters in the air and the guns of our ships at sea will not drown out the messages of Christmas which come to the hearts of our fighting men. The thoughts of these men tonight will turn to us here at home around our Christmas trees, surrounded by our children and grandchildren and their Christmas stockings and gifts—just as our own thoughts go out to them, tonight and every night, in their distant places. ${ }^{129}$

Here Roosevelt evoked both theaters of the war and the home front with equal power and with equal import. He invited the troops abroad to see Christmas at home even as those at home were asked to see the experience of the troops. ${ }^{130}$ Audiences were prompted not only to feel the meaning of Christmas but also to picture this idealized view of how the holiday appeared across the nation and across the world. By enabling emotional connections among his auditors through depiction, FDR established himself as the crucial link between those auditors and between them and the government, for he could see-and thus facilitate his audiences' vision — the entire picture. The nation had become synoptically unified. ${ }^{131}$

\section{Roosevelt's Vision}

It cannot be a coincidence that FDR, who communicated so frequently over radio, used such a preponderance of visual cues. In an era when visuality was integral to the national experience, visual language, as Cara Finnegan notes, would have resonated both widely and deeply. ${ }^{132}$ This resonance surely assisted Roosevelt’s efforts to mask his disability. ${ }^{133}$ But it had other consequences as well. Roosevelt didn’t simply encourage his listeners to see. He encouraged them to see as he saw, with the same clarity he brought to national and international issues, and with the same long-range vision that enabled action aimed at the future as well as the 
present. Such rhetoric, spoken so consistently for such a long time, helped establish his deep and intimate relationship with the American public for it brought them into his realm of experience even as he seemed to participate in theirs. William Gorham Rice, for instance, wrote the president on that, "What you said in your speech last night is exactly what our citizens needed to hear from one who is constantly surveying the situation,” indicating that FDR had made his experience clear to at least one member of his audience. ${ }^{134}$ Another correspondent noted that his speeches made him feel "very near." 135 There is no doubt that citizens felt closely connected to this president in a way that has few, if any, parallels.

During FDR's administration the public attitude toward the federal government changed and the vehicle for that change was the person of the president himself. Famously, the biggest ovation he received during his first inaugural was after his assertion that he would not hesitate to assume wartime power, a particularly chilling thought given the fervent isolationism of the period and the rise of dictators abroad. ${ }^{136}$ Members of the mass public felt connected to him and to his wife. They wrote to him in numbers that seem incredible. ${ }^{137}$ The White House received between 5,000 and 8,000 letters a day. ${ }^{138}$ They equated him with both Jesus and Moses. ${ }^{139}$ They hung his portrait in their homes. ${ }^{140}$ The lines that accompanied his funeral train from Georgia to Washington remain legendary. ${ }^{141}$ And they hated him with an intensity and venom that in itself was indicative of how personal and personalized his governance had become. ${ }^{142}$

Roosevelt worked hard to create and maintain the personal aspect of his power. He wooed the press, set very specific rules for his press conferences and he increased the number of staffers dedicated to news management by over 300 percent. ${ }^{143}$ He began his Fireside Chats with the homey greeting, "My friends,” and he did not hesitate to reach out to every audience in ways 
that tied the public's allegiance to him as much as to the government he led. And, importantly for my argument, his rhetoric created a participatory experience for listeners. ${ }^{144}$

That experience was instrumental to his overall task of encouraging the country to think, believe, and act as a nation; moving the center of political life from localities and states to the federal level; shifting the weight of power and influence over policy thus nationalized from the Congress to the Executive; and basing all of this on mediated communication that allowed the president to establish and maintain a "personal” relationship with the mass public. All of these were facilitated by Roosevelt's ability to enable his audience to visualize the nation as a whole and to participate in that vision.

That participation allowed FDR to organize the task of building an American state based upon the collection, abstraction and management of various localities. Under Roosevelt, politics, economics, and popular culture became more “mass” than vernacular. Nation building was accompanied by serious economic, political, and social dislocations. Many of these were both facilitated and masked by rhetoric relying on visuality and relying on claims to a shared national perspective. That rhetoric constituted a unified public with a clear vision of the national future. It excluded from that public those who did not share the president's vision.

He structured politics around group interests and opened the floodgates of lobbying. ${ }^{145}$ He opened Washington's doors to group pressure and managed those pressures himself through an artful and devious personalized system of policymaking. Centralized government exploded under his administration, leaving a legacy of governmental edifices strewn throughout the capital city and along its famous Mall and a bewildering structure of competing, overlapping, and contending departments and agencies. 
He brought mass media and the presidency together in ways that the nation had never seen before, ${ }^{146}$ and his style of personalized and personal politics, which worked so well for him, have had important consequences for the political system. As biographer James MacGregor Burns noted, "He took the role of national father, of bipartisan leader, of President of all the people. Playing this role with consummate skill, he extracted from it the last morsel of political power and government action.” ${ }^{147}$ His successors, less endowed with Roosevelt's skill, have nonetheless continued to play the roles Roosevelt created, and have increasingly aggrandized the office and raised our expectations concerning those who occupy it. This legacy permeates the language of modern presidential campaigns and these developments remain enormously consequential in the practice of contemporary politics.

FDR's rhetoric authorized one hegemonic view of national life, displaced local experiences of the nation, helped to legitimate a strong federal government and the rather paternalistic role of the chief executive within that government. It did these things while rendering its own hierarchies and exclusions invisible. It is important to note too, that this experience was not actually participatory. Even as citizens were feeling more strongly connected to the president, he was, in fact, further removed from them. Fewer people actually had direct access to the chief executive and as policy making became more bureaucratized and more national, there was less individual influence on policy that more directly impacted increasing numbers of people. ${ }^{148}$ Roosevelt argued consistently that sharing his vision, seeing through his eyes, enabled the protection of the vernacular on the national level and that the synoptic state was consistent with republican norms and democratic practices. But it is not so easy to reconcile democratic citizenship with a strong centralized state and a strong executive, for whenever the local is subsumed into the national, individuation is inevitably lost. The more politics moved to 
the national level, the more citizens were distanced from those politics and the harder presidents and presidential candidates must work to establish a "personal" connection to the mass public. These tensions, created during the Roosevelt era, continue to characterize our national politics, creating also a central set of issues for those who wish to understand the presidency, national citizenship, and the ways in which they influence one another. 
${ }^{1}$ Note, for instance, that the 2008 Republican Platform supported a federal language policy and called for improvements in disaster relief, restoration of the national infrastructure, increased job-training, farm aid, government involvement in nurturing new sources of energy and energy technology, and action on health care, education, and perhaps more startling, in regulating internet content (child pornography and gambling) and in the private lives of citizens (gay marriage and abortion). Regardless of one's political position on these issues, it is hard to argue that this platform signals an interest in reducing the size or scope of the national government. The full text of the platform is available here: http://www.presidency.ucsb.edu/ws/index.php?pid=78545\&st=\&st1=\#axzz1OgT9MKPq. Web site accessed June 11, 2011.

${ }^{2}$ The most consistent critic of such efforts is George C. Edwards, III. See especially his On Deaf Ears: The Limits of the Bully Pulpit (New York: Oxford, 2006), and The Strategic Presidency: Persuasion and Opportunity in Presidential Leadership (New York: Oxford, 2009). But see also arguments with and modification of his conclusions in Jeffrey E. Cohen, Going Local:

Presidential Leadership in the Post-Broadcast Age (New York: Cambridge University Press, 2010); B. Dan Wood, The Myth of Presidential Representation (New York: Cambridge University Press, 2009).

${ }^{3}$ The “modern presidency” conventionally begins with FDR. See Fred I. Greenstein, “Introduction,” 1-6, in Fred I. Greenstein, ed. Leadership in the Modern Presidency (Cambridge, Mass: Harvard University Press, 1988), 3. 
${ }^{4}$ Although see Thomas W. Benson, ed. American Rhetoric in the New Deal Era, 1932-1945 (East Lansing: Michigan State University Press, 2006); Halford R. Ryan, Franklin D. Roosevelt’s Rhetorical Presidency (New York: Greenwood, 1988).

${ }^{5}$ Charles Hurd, When the New Deal was Young and Gay (New York: Hawthorn Books, 1965), 10, 24.

${ }^{6}$ For a detailed discussion of this point, see A. J. Beitzinger, A History of American Political Thought (New York: Harper and Row, 1972), 511-538.

${ }^{7}$ For a discussion of this point, see Theodore H. Lowi, The Personal President: Power Invested, Promise Unfulfilled (Ithaca, NY: Cornell University Press, 1986).

${ }^{8}$ Martin J. Medhurst, ed. Before the Rhetorical Presidency (College Station: Texas A\&M University Press, 2008).

${ }^{9}$ See Karen S. Hoffman, Popular Leadership in the Presidency: Origins and Practices (Lanham, MA: Lexington Books, 2010); Melvin Laracey, The Presidents and the Public: The Partisan Story of Going Public (College Station: Texas A\&M University Press, 2002).

${ }^{10}$ John Gunther, Roosevelt in Retrospect (New York: Harper and Brothers, 1950), 23, 134. For a discussion of the press as both subservient to and critical of FDR, see Gary Dean Best, The Critical Press and the New Deal: The Press versus Presidential Power, 1933-1938 (Westport, Conn: Praeger, 1993).

${ }^{11}$ Benson, “American Rhetoric in the New Deal Era," ix-xxi in Benson, American Rhetoric in the New Deal Era, xi; Adam Cohen, Nothing to Fear: FDR's Inner Circle and the Hundred Days that Created Modern America (New York: Penguin, 2009), 81.

${ }^{12}$ Patrick J. Maney, The Roosevelt Presence: A Biography of Franklin D. Roosevelt (New York: Twayne Publishers, 1992), 70, 181. One critic goes so far as to assert that "Roosevelt was built 
by propaganda.” John T. Flynn, The Roosevelt Myth (New York: Devin Adair, 1948), 279.

Others are more moderate in their appraisals. See, for instance, Alan Brinkley, Franklin Delano Roosevelt (New York: Oxford, 2010), 2.

${ }^{13}$ Ryan, Roosevelt's Rhetorical Presidency, 19.

${ }^{14}$ For an interesting study of aural persuasion, see Greg Goodale, Sonic Persuasion: Reading

Sound in the Recorded Age (Urbana, Ill: University of Illinois Press, 2011).

${ }^{15}$ One biographer refers to him as a "master publicist.” Allan M. Winkler, The Politics of

Propaganda: The Office of War Information, 1942-1945 (New Haven: Yale University Press,

1978), 20. Another says that his influence was "so profound that it changed the English language.” Amity Shlaes, The Forgotten Man: A New History of the Great Depression (New York: Harper, 2007), 11. On his ability to enact instead of merely promise leadership, see Suzanne M. Daughton, “Metaphorical Transcendence: Images of the Holy War in Franklin Roosevelt’s First Inaugural,” Quarterly Journal of Speech 79(1993): 427-446. On his skill in managing the image of his health, various policies, and his communication in general, see Davis W. Houck, Rhetoric as Currency: Hoover, Roosevelt and the Great Depression (College Station: Texas A\&M University Press, 2001); Davis W. Houck, FDR and Fear Itself: The First Inaugural (College Station: Texas A\&M University Press, 2002); Davis W. Houck \& Amos Kiewe, FDR's Body Politics: The Rhetoric of Disability (College Station: Texas A\&M University Press, 2003).

${ }^{16}$ Jonathan Alter, The Defining Moment: FDR's Hundred Days and the Triumph of Hope (New York: Simon and Schuster, 2006), 256.

${ }^{17}$ Vanessa Beasley and Deborah Smith-Howell, “No Ordinary Rhetorical President: FDR’s Speechmaking and Leadership,” 1-32, in Benson, American Rhetoric, 3; Roanld Isetti, “The 
Moneychangers of the Temple: FDR, American Civil Religion, and the New Deal," Presidential Studies Quarterly 26(1996): 678-693; Halford Ross Ryan, “Roosevelt’s First Inaugural: A Study in Technique,” Quarterly Journal of Speech 65(1979): 137-149.

${ }^{18}$ Thomas B. Farrell, Norms of Rhetorical Culture (New Haven: Yale University Press, 1993), 86-87.

${ }^{19}$ This was true both for domestic and foreign policy. See Jean Edward Smith, FDR (New York: Random House, 2007), 487.

${ }^{20}$ Michael Osborn, “I’ve been to the Mountaintop: The Critic as Participant,” 149-166, in Michael Leff and Fred Kauffield, eds. Texts in Context: Critical Dialogues on Significant Episodes in American Public Rhetoric (Davis, CA: Hermagoras Press, 1989).

${ }^{21}$ Davis W. Houck, “Reading the Body in the Text: FDR's 1932 Speech to the Democratic National Convention,” Southern Communication Journal 63 (1997): 20-36.

${ }^{22}$ Cara Finnegan, “FSA Photography and the New Deal Visual Culture,” 115-155, in Benson, American Rhetoric.; Cara Finnegan, Picturing Poverty: Print Culture and FSA Photography (Washington, DC: Smithsonian, 2003), 2.

${ }^{23}$ Finnegan, Picturing Poverty, x. See also Lawrence W. Levine and Cornelia R. Levine, The People and the President: America's Conversation with FDR (Boston: Beacon Press, 2002$), 22$.

${ }^{24}$ Finnegan, Picturing Poverty, $\mathrm{x}$.

${ }^{25}$ Finnegan, Picturing Poverty, xi.

${ }^{26}$ On the relationship of authenticity to visuality, see Finnegan, Picturing Poverty, xiii.

${ }^{27}$ The material conditions of depression and war were also pivotal. I am focusing here not on those conditions but on the rhetoric that helped to authorize the changes they facilitated. 
${ }^{28}$ James C. Scott, Seeing Like a State: How Certain Schemes to Improve the Human Condition

Have Failed (New Haven, CT: Yale University Press, 1998).

${ }^{29}$ On Roosevelt's part in the creation of the national state, see Peri Arnold, Making the

Managerial Presidency: Comprehensive Reorganization Planning, 1905-1996 (Lawrence:

University Press of Kansas, 1998).

${ }^{30}$ For a personal account of these years, see Benjamin Roth, The Great Depression: A Diary, eds. James Ledbetter and Daniel B. Roth (New York: Public Affairs, 2009).

${ }^{31}$ Alter, Defining Moment, 2.

${ }^{32}$ Alter, Defining Moment, 2.

${ }^{33}$ Alter, Defining Moment, 2.

${ }^{34}$ Fiona Venn, The New Deal (Edinburgh: Edinburgh University Press, 1998), 7.

${ }^{35}$ M.J. Heale, Franklin D. Roosevelt: The New Deal and War (New York: Routledge, 1999), 10.

${ }^{36}$ Anthony J. Badger, FDR: The First Hundred Days (New York: Hill and Wang, 2008), 3.

${ }^{37}$ Quoted in Cohen, Nothing to Fear, 15.

${ }^{38}$ Quoted in Jon Meacham, Franklin and Winston: An Intimate Portrait of an Epic Friendship (New York: Random House, 2003), 40.

${ }^{39}$ For instance, the comment that "prosperity was just around the corner," widely, if unfairly, associated with Herbert Hoover, helped to undermine his leadership. See, Robert S. McElvaine, The Great Depression: America, 1929-1941 (New York: Three Rivers Press, [1989] 2009), 73.

${ }^{40}$ This is, of course, a problem associated with the politics of pre-emption. See Stephen Skowronek, The Politics Presidents Make: Leadership from John Adams to Bill Clinton, revised edition (Cambridge, Mass.: Belknap Press of Harvard University Press, 1997). For the issues specifically faced by Hoover, see pages 260-285. 
${ }^{41}$ Charles E. Coughlin, “The National Union for Social Justice,” November 11, 1934, 7-19, in

Charles E. Coughlin, A Series of Lectures on Social Justice (Detroit, MI: Condon, 1935), 7.

${ }^{42}$ For an insightful analysis of the importance of dictatorship to Roosevelt's rhetoric, see Davis

W. Houck and Mihela Nocasian, “FDR’s First Inaugural Address: Text, Context, and

Reception,” Rhetoric and Public Affairs, 5: (2002): 649-678.

${ }^{43}$ Alter, Defining Moment, 149.

${ }^{44}$ Ronald Edsforth, The New Deal: America's Response to the Great Depression (Malden, Mass:

Blackwell, 2000), 8.

${ }^{45}$ McElvaine, Great Depression, 81-82.

${ }^{46}$ Heale, Roosevelt, 4.

${ }^{47}$ For good overviews of this complicated set of issues, see Wayne S. Cole, Roosevelt and the Isolationists, 1932-1945 (Lincoln: University of Nebraska Press, 1983); Justin D. Doenecke and Mark A. Stoler, Debating Franklin D. Roosevelt’s Foreign Policies, 1935-1945 (Lanham, Mass: Rowman and Littlefield, 2005).

${ }^{48}$ Franklin D. Roosevelt, “Address at Oglethorpe University,” May 22, 1932, 639-647, in Samuel I. Rosenman, ed, The Public Papers and Addresses of Franklin D. Roosevelt (New York: Random House, 1939), 646. Rosenman edited 13 volumes of papers and addresses; the first 6 were published in 1938 by Random House, the others by MacMillan in 1950. All volumes are abbreviated below as Public Papers.

${ }^{49}$ One author reports the number deaths as a result of the war "an unimaginable 50 million people.” Doris Kearns Goodwin, No Ordinary Time: Franklin and Eleanor Roosevelt: The Home Front in World War II (New York: Simon and Schuster, 1994), 621.

${ }^{50}$ Ernest K. Lindley, The Roosevelt Revolution First Phase (New York: Viking, 1933), 4. 
${ }^{51}$ Edsforth, New Deal, 9; Terry Golway, Together We Cannot Fail: FDR and the American

Presidency in Years of Crisis (Naperville, Ill: Sourcebooks, 2009), 40.

${ }^{52}$ In his Introduction to the first volume of his presidential papers and addresses, for instance, he wrote, “Consistently I have sought to maintain a comprehensive and efficient functioning of the representative form of democratic government in its modern sense. Consistently I have sought through that form of government to help our people to gain larger social justice.” Franklin D. Roosevelt, “General Introduction,” ix-xix, Public Papers, xiii.

${ }^{53}$ Scott, Seeing Like a State, 2 . This process has been insightfully studied as it played out in China. See Robert Hariman and John Louis Lucaites, No Caption Needed: Iconic Photographs, Public Culture, and Liberal Democracy (Chicago: University of Chicago Press, 2007), chapter 7. ${ }^{54}$ Scott, Seeing Like a State, 51.

${ }^{55}$ For a good compendium of research on the relationship between visuality and democracy, see Lester C. Olson, Cara A. Finnegan, and Diane S. Hope, eds. Visual Rhetoric: A Reader in Communication and American Culture (Sage: Thousand Oaks, CA: 2008).

${ }^{56}$ Yaron Ezrahi traces this phenomenon, at least as far as the United States is concerned, to the insistence on transparency by rhetors such as Thomas Paine and Thomas Jefferson. See Yaron Ezrahi, “Technology and the Civil Epistemology of Democracy,” 159-171 in Andrew Feenberg and Alastair Hannay, eds. Technology and the Politics of Knowledge (Bloomington: Indiana University Press, 1995), 161.

${ }^{57}$ Ezrahi, “Technology and the Civil Epistemology of Democracy,” 160.

${ }^{58}$ Ezrahi, “Technology and the Civil Epistemology of Democracy,” 163.

${ }^{59}$ I am indebted to Nathan Atkinson for his thoughts on this point.

${ }^{60}$ Franklin D. Roosevelt, “Second Inaugural Address,” January 20, 1937, 1-6, Public Papers, 5. 
${ }^{61}$ Alter, Defining Moment, 82.

${ }^{62}$ Thomas Farrell argues that this period was characterized by a changed understanding of the role of work in American political culture. Farrell, Norms of Rhetorical Culture, 84.

${ }^{63}$ Franklin D. Roosevelt, "Extemporaneous Address before the Code Authorities of Six Hundred Industries,” March 5, 1934, 123-132, Public Papers, 123-124.

${ }^{64}$ Farrell, Norms of Rhetorical Culture, 89.

${ }^{65}$ Roosevelt, “Inaugural Address,” March 4, 1933, 11-16, Public Papers, 14.

${ }^{66}$ On the rhetoric of purification, see Chaim Perlman and Lucie Olbrechts-Tyteca, The New Rhetoric: A Treatise on Argumentation (Notre Dame, IN: University of Notre Dame Press, 1971), 439-442.

${ }^{67}$ Franklin D. Roosevelt, “Annual Message to the Congress,” January 3, 1934, 8-14, Public Papers, 8.

${ }^{68}$ See Houck, "Reading the Body”; Houck and Kiewe, FDR's Body Politics.

${ }^{69}$ Arthur M. Schlesinger, The Age of Roosevelt: The Coming of the New Deal (Boston, Mass: Houghton Mifflin, 1959), 5, 10. On his disinterest in radical reform, see also Frances Perkins, The Roosevelt I Knew (New York: Viking, 1946), 328.

${ }^{70}$ Roosevelt, “Inaugural,” 12.

${ }^{71}$ Roosevelt used an extraordinary amount of religious language in his public address, prompting biographer James MacGregor Burns to write, "Probably no American politician has given so many speeches that were essentially sermons rather than statements of policy.” James MacGregor Burns, Roosevelt: The Lion and the Fox, 1882-1940 (New York: Harcourt, Brace, Jovanovich, 1956), 476. Citizens responded to him by suggesting that he dispelled darkness and 
brought light. See Lawton L. Brown, “Letter to the President,” October 16, 1937, Levine and Levine, People and the President, 211.

${ }^{72} \mathrm{He}$ almost always referred to "religion” and "Christianity” as synonyms, although he would sometimes exert some effort to ground "religion" in the Old Testament and thus include members of the Jewish faith. See, for example, Franklin D. Roosevelt, "Fireside Chat on the War in Europe," September 3, 1939, 460-464, Public Papers, 463. On his sectarian openmindedness, see Richard V. Pierard and Robert D. Linder, Civil Religion and the Presidency (Grand Rapids, MI: Zondervon Publishing, 1988), 170-171.

${ }^{73}$ W. S. Throckmorton, “Letter to the President,” October 17, 1935, President’s Personal File 21 (X-Ref’s) 21A (AL-AZ) Cont. 2; PPF 21A Clergy Letters, Alabama, Franklin D. Roosevelt Library, Hyde Park, New York.

${ }^{74}$ T. J. Gross, “Letter to the President,” October 18, 1935, President’s Personal File 21 (X-Ref's) 21A (AL-AZ) Cont. 2; PPF 21A Clergy Letters, Alabama, Roosevelt Library.

${ }^{75}$ Roosevelt, “Address Before the National Conference of Catholic Charities,” October 4, 1933, 379-382, Public Papers, 379.

${ }^{76}$ Isetti, "Moneychangers of the Temple."

${ }^{77}$ Franklin D. Roosevelt, “Address at Denton, Maryland,” September 5, 1938, 512-520, Public Papers, 513.

${ }^{78}$ Franklin D. Roosevelt, “The President Urges the Extraordinary Session to Repeal the Embargo Provisions of the Neutrality Law,” September 21, 1939, 512-525, Public Papers, 521.

${ }^{79}$ Franklin D. Roosevelt, “Acceptance of the Renomination for the Presidency,” June 27, 1936, 230-236, Public Papers, 231. 
${ }^{80}$ Franklin D. Roosevelt, “Address at San Diego Exposition, San Diego, California,” October 2, 1935, 405-412, Public Papers, 405-412, 410.

${ }^{81}$ Franklin D. Roosevelt, “Fireside Chat on the War in Europe,” September 3, 1939, 460-464, Public Papers, 464.

${ }^{82}$ Franklin D. Roosevelt, “A Letter to the Pope in the Interest of Paralleling Endeavors for Peace and Alleviating Suffering,” December 23, 1939, 606-608, Public Papers, 607.

${ }^{83}$ Franklin D. Roosevelt, “Address at Notre Dame University,” 493-496, Public Papers, 495-496.

${ }^{84}$ Franklin D. Roosevelt, “Message to Congress Asking Additional Appropriations for National Defense,” May 6, 1940, 198-212, Public Papers, 198.

${ }^{85}$ Roosevelt, “Second Inaugural,” 5.

${ }^{86}$ See, for example, Hugh Gary, “Letter to the President,” September 28, 1935, President’s Personal File 21A (CA-CT) Cont 5; PPF 21A Clergy Letters, Colorado, Roosevelt Library; Duncan S. Merwin, “Letter to the President,” October 7, 1935, President's Personal File 21A (CA-CT) Cont 5; PPF 21A Clergy Letters, California, Roosevelt Library. Others also made this connection in other circumstances. See Charles Arthus J. Conlin to Stanley High, June 4, 1936, Good Neighbor League Papers, Correspondence File, General Organization—Barr, Louis D.— GNL Campaigns and Programs_-Objectives and Purposes of GNL, Cont 8; Good Neighbor League General Organization Letters to and From the Clergy, Roosevelt Library. ${ }^{87}$ Franklin D. Roosevelt, “Address Broadcast from a Naval Base on the Pacific Coast to the Democratic National Convention in Chicago,” July 20, 1944, 201-206, Public Papers, 203. ${ }^{88}$ Franklin D. Roosevelt, “Address Delivered at Green Bay, Wisconsin,” August 9, 1934, 370375, Public Papers, 372. 
${ }^{89}$ Franklin D. Roosevelt, “Annual Message to Congress,” January 3, 1940, 1-10, Public Papers, 3.

${ }^{90}$ Roosevelt, “Annual Message to Congress,” January 3, 1940, 4.

${ }^{91}$ Franklin D. Roosevelt, “A Fireside Chat Discussing Legislation to be Recommended to the Extraordinary Session of the Congress,” October 12, 1937, 429-438, Public Papers, 430.

${ }^{92}$ D.P. Alterman, “Letter to the President,” October 13, 1937, Levine and Levine, People and the President, 214.

${ }^{93}$ George H. Allen, “Letter to the President,” April 14, 1938, President’s Personal File, 200B (4/14/38: Radio Broadcast; S-Z Pro, A-F Con) Cont 50; File PPF 200B Public Reaction April 14, 1938, Radio Broadcast, Con A-F, Roosevelt Library.

${ }^{94}$ Frank C. Reilly, “Telegram to the President,” October 1, 1934, Levine and Levine, People and the President, 119.

95 John H. Small, “Telegram to the President,” September 30, 1934, President’s Personal File, 200B (9/30/34: M-Z: 12/10/34 Cont 19; File PPF 200B Public Reaction September 30, 1934, S, Roosevelt Library.

${ }^{96}$ See W.O. Laube, “Letter to the President,” October 7, 1935, President’s Personal File 21A (Church Officials; Miscellaneous) Cont 35; PPF 21A Clergy Letters, Authors and Editors, Roosevelt Library.

${ }^{97}$ See Philip R. Dunbar, “Letter to the President,” April 15, 1938, President’s Personal File, 200B (4/14/38: Radio Broadcast; S-Z Pro, A-F Con) Cont 50; File PPF 200B Public Reaction April 14, 1938, Radio Broadcast, Con A-F, Roosevelt Library.

${ }^{98}$ Many correspondents commented on his “vision” and far-sightedness. See, for example, Walker, M. Sage, “Letter to the President,” September 23, 1935, President’s Personal File 21A 
(CA-CT) Cont 5; PPF 21A Clergy Letters, California, Roosevelt Library; Harry B. Lee, "Letter to the President," September 27, 1935, President’s Personal File 21A (CA-CT) Cont 5; PPF 21A Clergy Letters, California, Roosevelt Library; Paul Tanner, “Letter to the President,” September 26, 1935, President’s Personal File 21A (WV Church Officials) Cont 34; PPF 21A Clergy Letters, Wisconsin, Roosevelt Library.

${ }^{99}$ Franklin D. Roosevelt, “Fourth Fireside Chat,” October 22, 1933, 420-429, Public Papers, 420. ${ }^{100}$ Roosevelt, “Inaugural,” 15.

${ }^{101}$ Maney, Roosevelt Presence, 53. On FDR's lack of an actual program for recovery, see most famously, Burns, Lion and the Fox, 143.

${ }^{102}$ Maney, Roosevelt Presence, 69.

${ }^{103}$ Manuel Mendes, “Letter to the President,” March 26, 1937, Levine and Levine, People and the President, 179; Gustavus Harkness, “Letter to the President,” March 11, 1937, Levine and Levine, People and the President, 197.

${ }^{104}$ Ryan, Rhetorical Presidency, 9.

${ }^{105}$ Roosevelt, “Annual Message to Congress,” January 4, 1935, 15-25, Public Papers, 15.

${ }^{106}$ On small minorities, see Franklin D. Roosevelt, “Third Fireside Chat,” July 24, 1933, Public Papers, 300. On pettiness, see Franklin D. Roosevelt, “Address to the White House Correspondents’ Association,” February 12, 1943, 71-81, Public Papers, 75. On disproportionate power, see Franklin D. Roosevelt, “Annual Message to Congress,” January 3, 1936, 8-18, Public Papers, 13.

${ }^{107}$ See, for example, Franklin D. Roosevelt, "A Message to Congress on Pure Food and Drugs," March 22, 1935, 110-11, Public Papers, 111.

${ }^{108}$ Roosevelt, “Third Fireside Chat,” 300. 
${ }^{109}$ Franklin D. Roosevelt, “Address Before the American Legion Convention, Chicago, Illinois,” October 2, 1933, 373-382, Public Papers, 373.

${ }^{110}$ Roosevelt, “Pure Food and Drugs,” 111.

${ }^{111} \mathrm{~A}$ number of correspondents used expressions relating to size and proportion in their letters.

See F. M. Warden, “Letter to the President,” October 8, 1935, President’s Personal File 21A

(WV Church Officials) Cont 34; PPF 21A Clergy Letters, Wyoming, Roosevelt Library; Paul A.

Schoch, “Letter to the President,” October 4, 1934, President’s Personal File, 200B (9/30/34: M-

Z: 12/10/34 Cont 19; File PPF 200B Public Reaction September 30, 1934, S, Roosevelt Library.

${ }^{112}$ These juxtapositions run throughout a number of his speeches, but see, for instance, Franklin

D. Roosevelt, “Address at Dedication of Boulder Dam,” September 30, 1935, 397-402, Public

Papers.

${ }^{113}$ Roosevelt, "Fourth Fireside Chat,” 420.

${ }^{114}$ For a discussion of how FDR's physical body served as a rhetoric resource throughout the Roosevelt years, see Houck and Kiewe, FDR's Body Politic.

${ }^{115}$ Roosevelt, “A Fireside Chat Discussing Legislation to be Recommended to the Extraordinary Session of the Congress,” 430.

${ }^{116}$ He dealt with these fears both directly and indirectly. His direct comments, which do not generally involve ocular metaphors, do not concern me here, but see Franklin D. Roosevelt, “The President Refutes Dictatorship Charges Connected with the Pending Reorganization Bill,” March 29, 1938, 179-192, Public Papers, 179. For an example of public fears of dictatorship, see R.B. Fisher, “Letter to the President,” September 28, 1935, President’s Personal File 21A (IA-KS) Cont 11; PPF 21A Clergy Letters, Iowa, Roosevelt Library. 
${ }^{117}$ The Levines write, "Even when people listened alone, the experience could be a communal one.” Levine and Levine, People and the President, 21. See also Goodale, Sonic Persuasion.

${ }^{118}$ Glenn B. Coykendall, “Letter to the President,” October 23, 1935, President’s Personal File 21 (1934-45; X-Ref's, 1933-43), Cont 1; PPF 21 Church Matters, 1934-43, Roosevelt Library.

${ }^{119}$ Thomas C. Darst, “Letter to the President,” October 3, 1935, President’s Personal File 21A (Church Officials; Miscellaneous) Cont 35; PPF 21A Clergy Letters, Bishops, Roosevelt Library. ${ }^{120}$ William H. Watts, “Letter to the President,” October 18, 1935, President’s Personal File 21A (NY-NJ) Cont 20; PPF 21A Clergy Letters, New Jersey, Roosevelt Library. See also Charles B. Merritt, “Letter to the President,” October 2, 1934, President’s Personal File, 200B (9/30/34: MZ: 12/10/34 Cont 19; File PPF 200B Public Reaction September 30, 1934, M, Roosevelt Library. Opponents also used visual language to describe their reactions to his speeches; one correspondent rebuked Roosevelt for failing to provide "a real picture.” Richard E. Clark, “Telegram to the President,” October 26, 1934, President’s Personal File, 200B (9/30/34: M-Z: 12/10/34 Cont 19; File PPF 200B Public Reaction October 24, 1934, Roosevelt Library. Another critic accused him of concealment regarding his treatment of Charles A. Lindbergh. Margaret Oliver, "Letter to the President,” August 10, 1941, Official File 92, Lindbergh, Charles A/ OF 93 Colored Matters (Negroes) Box \#2 Box \#1; OF 92, Charles A. Lindbergh, Aug-Dec 1941. Still others wrote to him offering to help "expose the real motives” of Roosevelt's opponents. See A. Gordon, “Letter to the President,” August 27, 1925, Official File 1144-1157, OF 1150, American Liberty League, August, 1935.

${ }^{121}$ Franklin D. Roosevelt, “Address at Jackson Day Dinner,” January 8, 1940, 25-35, Public Papers, 31. 
${ }^{122}$ Franklin D. Roosevelt, "The President Urges the Congress to Pass Additional Appropriations for National Defense,” January 12, 1939, 70-76, Public Papers, 74.

${ }^{123}$ Partly, of course, this is an artifact of the fact that Roosevelt was president, and a great deal of interpretive authority comes with that office. It is also notable that many citizens who wrote Roosevelt referred to their narrow perspective and compared it to his larger one. See, for example, Richard G. Deffner, “Letter to the President,” January 6, 1936, President’s Personal File 21 (X-Ref’s) 21A (AL-AZ) Cont. 2; PPF 21A Clergy Letters, Arizona, Roosevelt Library; Lewis Thompson Smith, “Letter to the President,” March 2, 1942, Levine and Levine, People and the President, 429.

${ }^{124}$ See, for example, Franklin D. Roosevelt, “The Securities Bill is Signed. The President Issues a Statement,” May 27, 1933, 213-215, Public Papers, 213-214; Franklin D. Roosevelt, "Radio Address Before the Pan American Governing Board,” April 15, 1940, 158-162, Public Papers, 161; Franklin D. Roosevelt, "The President Asks the Congress to Authorize the Arming of Merchant Ships and to Revise the Neutrality Act,” October 9, 1941, 406-413, Public Papers, 406, 410. Critics were often unhappy about this. See James E. Crowther, "Letter to the President,” September 27, 1935, President’s Personal File 21A (CA-CT) Cont 5; PPF 21A Clergy Letters, Colorado, Roosevelt Library.

${ }^{125}$ That vision transcended geography. One correspondent told the president that "We in this western corner of our great country, believe in you, your vision, your ideals, and your integrity.” Mrs. H. C. St. John, “Letter to the President,” September 30, 1934, President’s Personal File, 200B (9/30/34: M-Z: 12/10/34 Cont 19; File PPF 200B Public Reaction September 30, 1934, S, Roosevelt Library. Others urged him to speak more often because of his unifying and persuasive effect. Edwin E, Jones, “Letter to the President,” January 3, 1936, President’s Personal File, 
200B (1/3/36: H-M) Cont 126; File PPF 200B Public Reaction January 3, 1936, H, Roosevelt Library.

${ }^{126}$ On depiction, and the combination of aesthetics and content, see Michael Leff and Andrew Sachs, "Words the Most Like Things: Iconicity and the Rhetorical Text," Western Journal of Speech Communication 54(Summer 1990): 252-273.

${ }^{127}$ David M. Kennedy, Freedom From Fear: The American People in Depression and War, 1929-1945 (New York: Oxford University Press, 1999), 137.

${ }^{128}$ See, for example, Joseph J. Hitov, “Letter to the President,” April 28, 1942, Levine and Levine, People and the President, 449; James J. Dunn, “Letter to the President,” May 16, 1933, Levine and Levine, People and the President, 68; Frank W. Hadley, "Letter to the President," June 24, 1933, Levine and Levine, People and the President, 83; Nat Baumann, "Letter to the President,” April 14, 1938, Levine and Levine, People and the President, 237.

${ }^{129}$ Franklin D. Roosevelt, “A Christmas Address to the Nation,” December 24, 1944, 444-445, Public Papers, 444.

${ }^{130}$ Although his purposes are different than mine, John Murphy understands this as a problem of presence. Relying on Perelman and Olbrechts-Tyteca's use of the term, Murphy argues that Roosevelt relied on three argumentative stylistic tactics to make the European war present to Americans and to overcome isolationism. For Murphy, those tactics are analogy, visual language, and shrinking time and space. John M. Murphy, "No End Save Victory: FDR and the End of Isolationism 1936-1941," in Making the Case: Studies in Public Advocacy in Honor of David Zarefsky, eds. Kathryn Olson, Kirt Wilson, and Michael Pfau (East Lansing: Michigan State University Press, in press). On the idea of presence, see Perelman and Olbrechts-Tyteca, New Rhetoric, 115-120. 
${ }^{131}$ Certainly, those who understood him as "Moses" were making constitutive claims. See, for example, J.A. Hawkes, “Letter to the President,” October 15, 1935, President’s Personal File 21A (WV Church Officials) Cont 34; PPF 21A Clergy Letters, Wisconsin, Roosevelt Library. This is a particularly interesting letter for while the author wrote FDR that he "welcomed you as a Moses," he also refused to follow "in the direction” of "a communistic dictatorship." Others simply promised to "pull together" as a result of one of his speeches. See J. Guy McQuitty, “Letter to the President,” September 30, 1934, President’s Personal File, 200B (9/30/34: M-Z: 12/10/34 Cont 19; File PPF 200B Public Reaction September 30, 1934, M, Roosevelt Library. Poet Ruth Albert Cook also noted his ability to unite the nation and to do so on the basis of important inclusions, even if both the unity and the inclusion were, for her, ephemeral. See the poem quoted at length in Levine and Levine, People and the President, 561, ${ }^{132}$ Finnegan, Picturing Poverty, ix-xiv.

${ }^{133}$ Houck, "Reading the Body."

${ }^{134}$ William Gorham Rice, “Letter to the President,” October 1, 1934, President’s Personal File, 200B (9/30/34: M-Z: 12/10/34 Cont 19; File PPF 200B Public Reaction September 30, 1934, QR, Roosevelt Library. See also, William F. Pashby, “Letter to the President,” October 1, 1934, President’s Personal File, 200B (9/30/34: M-Z: 12/10/34 Cont 19; File PPF 200B Public Reaction September 30, 1934, O-P, Roosevelt Library.

${ }^{135}$ E. F. McGrath, “Letter to the President,” September 30, 1934, President’s Personal File, 200B (9/30/34: M-Z: 12/10/34 Cont 19; File PPF 200B Public Reaction September 30, 1934, M, Roosevelt Library; emphasis in original. See also, Virginia Miller, "Letter to the President," March 3, 1933, Levine and Levine, People and the President, 45.

${ }^{136}$ Schlesinger, Age of Roosevelt, 1. 
${ }^{137}$ For a discussion of the role these letters played in FDR's rhetoric, see Gerard A. Hauser, Vernacular Voices: The Rhetoric of Publics and Public Spheres (Columbia: University of South Carolina Press, 1999), 232-267.

${ }^{138}$ Maney, Roosevelt Presence, 71.

${ }^{139}$ Farrell, Norms of Rhetorical Culture, 89; Davis W. Houck and Mihaela Nocasian, “FDR’s First Inaugural Address”; Isetti, “Moneychangers of the Temple,”; McElvaine, Great Depression, 116.

${ }^{140}$ McElvaine, Great Depression, 115.

${ }^{141}$ See Robert Klara, FDR's Funeral Train: A Betrayed Widow, a Soviet Spy, and a Presidency in the Balance (New York: Palgrave MacMillan, 2011).

142 Burns, The Lion and the Fox, 337-338; Schlesinger, Age of Roosevelt, 567.

143 There were 68 publicists when FDR took office. By 1937, there were over 300. See Best, Critical Press and the New Deal, 8.

${ }^{144} \mathrm{~A}$ number of correspondents, for instance, noted the importance of working together with the president to facilitate national goals. See, for example, Howard A. Clark, "Letter to the President,” no date, President’s Personal File 21 (X-Ref's) 21A (AL-AZ) Cont. 2; PPF 21A Clergy Letters, Arizona, Roosevelt Library; and of providing local facts to facilitate national policy. See Robert O. McNeal, “Letter to the President,” January 3, 1936, President’s Personal File, 200B (1/3/36: H-M) Cont 26; File PPF 200B Public Reaction January 3, 1936, K, Roosevelt Library; F.J. Dillon, “Telegram to the President,” January 4, 1936, President’s Personal File, 200B (1/3/36: H-M) Cont 126; File PPF 200B Public Reaction January 3, 1936, H, Roosevelt Library.

${ }^{145}$ Shlaes, Forgotten Man, 10-11. 
${ }^{146}$ Alter, Defining Moment, 356-264.

${ }^{147}$ Burns, The Lion and the Fox, 183.

${ }^{148}$ Maney, The Roosevelt Presence, 75. 